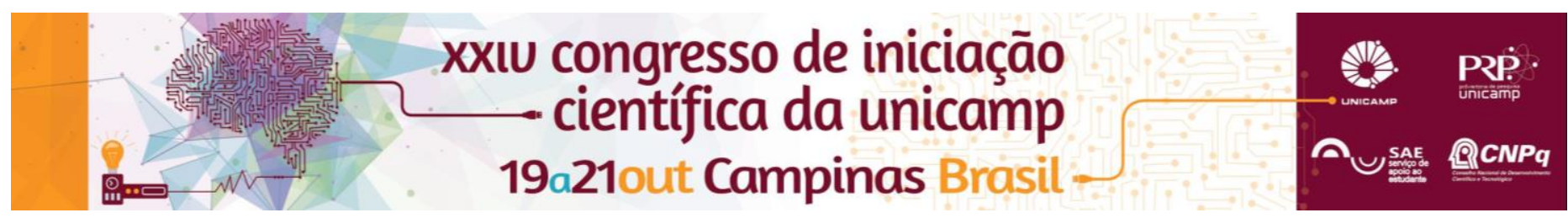

\title{
Participação da morte celular induzida por ácidos graxos de cadeia curta na resolução da inflamação.
}

\author{
Breno Pazinatto Antonio*, Érica Sernaglia, Aline Vieira, Marco Aurélio Ramirez Vinolo
}

\begin{abstract}
Resumo
Os neutrófilos são células essenciais na resposta imune a microrganismos. Bactérias podem modificar, direta ou indiretamente, o processo de morte de neutrófilos, podendo ser relevante para a resposta imune. Ao entrar em apoptose essas células são reconhecidas e fagocitadas por macrófagos (eferocitose), os quais por sua vez modificam o seu perfil de pró-inflamatório para anti-inflamatório. No presente projeto analisamos a relevância da indução de morte de neutrófilos por produtos do metabolismo bacteriano (os ácidos graxos de cadeia curta, AGCCs) no que diz respeito a capacidade de macrófagos fagocitarem neutrófilos (eferocitose) e sua resposta efetora incluindo produção de citocinas e killing de bactérias. Nossa hipótese é que a produção de AGCCs por bactérias patogênicas tem um papel relevante tanto no que diz respeito a ação do sistema imune quanto aos danos teciduais decorrentes da ativação desse sistema.
\end{abstract}

\section{Palavras-chave:}

Neutrófilos, macrófagos, resposta imune.

\section{Introdução}

A morte de neutrófilos por apoptose e sua remoção, processo esse feito pelos fagócitos e denominado eferocitose, ajuda a limitar o dano tecidual. ${ }^{3}$ Os AGCCs, são gerados durante o processo de fermentação bacteriana e são encontrados em altas concentrações nas gengivas de indivíduos com doença periodontal. 1,2

Sabemos que os AGCCs induzem morte celular em neutrófilos, sendo assim temos como objetivo, investigar o papel desses AGCCs no processo inflamatório e resposta imune a bactérias.

\section{Resultados e Discussão}

1-Efeito dos AGCCs sobre a morte de neutrófilos. Foi adicionado ácidos graxos aos neutrófilos. Após análise por citometria de fluxo, verificamos que na presença do butirato (concentrações de 1 e $5 \mathrm{mM}$ ) a viabilidade das células foi significativamente reduzida. Esse tratamento desencadeou o processo apoptose em neutrófilos conforme evidenciado pelo aumento de células positivas para anexina, assim como de fragmentação de DNA. 2-Efeito da pré-incubação de neutrófilos com AGCCs sobre a eferocitose. Neutrófilos GFP+ foram incubados em placas de baixa adesão, tanto na presença quanto ausência de AGCCs, em seguida foram retirados da placa, e adicionados à placa contendo os macrófagos. Esses macrófagos foram analisados por citometria de fluxo. Os neutrófilos pré-tratados com AGCCs por 4 horas não alteraram a eferocitose por macrófagos (Fig. 1A).

3- Efeito da pré-incubação de neutrófilos com AGCCs sobre a expressão de citocinas. A expressão do gene TNF- $\alpha$ por macrófagos incubados com neutrófilos é aumentada (Fig 1 B), porém, essa expressão diminui significativamente quando os neutrófilos são tratados previamente com butirato. Por outro lado, macrófagos incubados com neutrófilos mantiveram a expressão do gene IL-10, porém, ao tratar os neutrófilos com butirato 5 $\mathrm{mM}$, houve um aumento significativo nessa expressão desse gene.

4-Efeito da pré-incubação de neutrófilos com AGCCs sobre 0 killing de E.coli por macrófagos. Este experimento foi realizado com 0 intuito de analisar o efeito dos neutrófilos pré-incubados na presença ou ausência de AGCCs sobre a capacidade microbicida dos macrófagos. Não houve uma diferença significativa entre as 3 condições analisadas: macrófagos, macrófagos préincubados com neutrófilos e macrófagos pré-incubados com neutrófilos previamente tratados com butirato. Sendo assim é possível afirmar que a presença de neutrófilos (tratados ou não com AGCCs), não interfere na capacidade microbicida dos macrófagos.
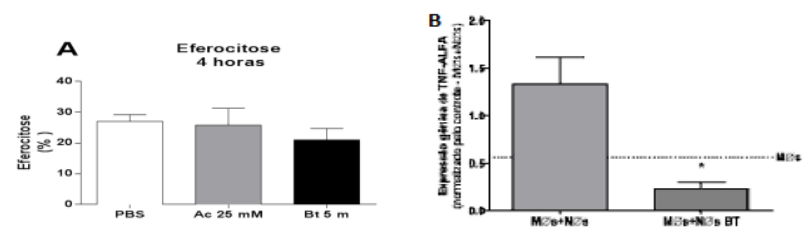

Figura 1A. Análise quantitativa da ocorrência de eferocitose e resposta de macrófagos pré-incubados com neutrófilos a estimulação com LPS.

Figura 1B. Efeito da pré-incubação de neutrófilos com AGCCs sobre a expressão de citocinas por macrófagos estimulados com LPS.

\section{Conclusões}

Com os resultados conclui-se que a presença do butirato, reduz a viabilidade celular, gerando apoptose em neutrófilos. Contudo, não há alteração na eferocitose nas condições com AGCCs. Com relação a expressão de citocinas, concluímos que ao incubar macrófagos com neutrófilos, previamente tratados com butirato, diminui a expressão de TNF- $\alpha$ e aumenta a de IL-10, mostrando um perfil anti-inflamatório, porém quando analisamos a influência de neutrófilos (tratados ou não com AGCCs) sobre a capacidade microbicida dos macrófagos, notamos que não ocorre diferença significativa.

\footnotetext{
1 Kurita-Ochiai, T., K. Fukushima, et al. (1995). "Volatile fatty acids, metabolic by-products of periodontopathic bacteria, inhibit lymphocyte proliferation and cytokine production." J Dent Res 74(7): 1367-1373.

${ }^{2}$ Niederman, R., Y. Buyle-Bodin, et al. (1997). "Short-chain carboxylic acid concentration in human gingival crevicular fluid." J Dent Res 76(1): 575-579.

3Vinolo, M. A., H. G. Rodrigues, et al. (2011). "Regulation of inflammation by short chain Fatty acids." Nutrients 3(10): 858-876.
} 